\title{
Job Satisfaction and Organizational Commitment as Determinants of Teacher Performance
}

\author{
Rini Anggraeni, Rasto \\ Faculty of Economics and Business Education \\ Universitas Pendidikan Indonesia \\ Setiabudhi No. 229 Bandung \\ rinianggraeni@student.upi.edu,rasto@upi.edu
}

\begin{abstract}
- the purpose of this study was to analyze influence job satisfaction and organizational commitment on teacher performance. This research used survey method. Data collection techniques used question form with rating scale model on scale of 1-5. Respondents are teachers of vocational high schools in Bandung. Data were analyzed using regression. The result of the study revealed that job satisfaction and organizational commitment, partially and simultaneously, have positive and significant influence on teacher performance. Thus the teacher performance can be improved through increased job satisfaction and organizational commitment.
\end{abstract}

Keywords - job satisfaction, organizational commitment, teacher performance

\section{INTRODUCTION}

Teacher performance is always interesting to study. This is not apart from the strategic position of teachers in education and education for the strategic positioning of a nation.

Education is the fundamental of the development of modern society [1]. Education is the basic factor in the success or failure of a person individually and of a nation as a whole [2] and the most important determinant of social and economic growth of a country [3].

Education in a country is organized through the education system. The progress of any country is dependent on its educational system, and the education system will be accomplished by right and effective teaching staffs [4][5]. Thus teachers have important and central position [6][7] as key asset [8] and most precious for nation and country [9]. Teachers play as pillars [10], pivot [11], backbone [12], and the corner stone [13] from execution of education system. At school, teacher directly play for achieving school effectiveness [8][14][15], and the primary source of competitive advantage in schooling [16].

Several previous studies showed that teacher performance is not optimal. This is reflected in the unattractive and conventional learning process, the teachers come late to the class; the students' learning outcomes have not met the standards; and the attendance of teachers in schools fluctuates. The immediate question is why the teacher performance is not optimal? Referring to the perspective of behavioral theory, many factors can affect the teacher performance. Job satisfaction and organizational commitment are two factors that allegedly affect the teacher performance.

Based on this, the problem statement for this research was "are job satisfaction and organizational commitment having influence on teacher performance?" Therefore, the purpose of this study is to analyze the effect of job satisfaction and organizational commitment on teacher performance.

\section{TEACHER PERFORMANCE}

Performance is generally defined as the record of outcomes produced during a specified time period [17]. Therefore, performance always is known from aspect of result, not the effort that someone does, that is how well individual meet their job demand [18]. In this sense, teacher performance is closely related to the tasks as a professional teacher relying on the required ability [19][7]. Teacher performance is very important in the fields of education [14], and performance plays a key role in student learning and academic achievement [11].

Teacher performance is affected by many factors. This study only examined two factors: organizational commitment and job satisfaction. It was based on the argument that performance depends on degree of organizational commitment and job satisfaction [9].

\section{JOB SATISFACTION}

Job satisfaction is a must on the part of every profession, include teacher [4]. Job satisfaction is an important construct that influences the organizational behavior of teachers because it contributes to the study of organizational and teaching effectiveness [1][6][9][20][21], and leads to a number of consequences [22]. People will feel successful in carrying out his or her tasks [19], and they are more involved to their job [23] if they feel job satisfaction [24].

Job satisfaction or employee satisfaction can be defined in many ways [3]. Job satisfaction is a result of employee's perception [25] and attitudes possessed by employees that related to their job [26]. Job satisfaction is a global feeling [27], general attitude [28], general opinion [9], and general reaction towards his/her job [29]. Job satisfaction on the other 
hand is employees' cognitive, affective and evaluative reactions towards their job [24].

Job satisfaction indicates whether the teachers do or do not like their job [9][15][30]. Therefore, job satisfaction is positive and negative emotions to their job [3][13][20][22][31]. Positive emotion shows pleasurable emotion from someone to his/her job [1][24] that describes how happy a person is with his/her job [32].

Job satisfaction is also defined as a match between the employees expectations of the job and the rewards that the job provides [28][33], concerned with how well an employee's expectations at work are in tune with outcomes [9], and difference between the amount of rewards workers received and the amount they believe they should receive [28].

Job satisfaction can be measured through indicators exit, voice, loyalty and neglect [34]. Exit is response directs behavior toward leaving the organization, including looking for a new position as well as resigning. The voice response includes actively and constructively attempting to improve conditions, including suggesting improvements, discussing problems with superiors, and undertaking some forms of union activity. The loyalty response means passively but optimistically waiting for conditions to improve, including speaking up for the organization in the face of external criticism and trusting the organization and its management to "do the right thing. The neglect response passively allows conditions to worsen and includes chronic absenteeism or lateness, reduced effort, and increased error rate.

\section{ORGANIZATIONAL COMMITMENT}

Organizational commitment is one of the most important predictor for achieving organizational success. Therefore, committed employees are valuable assets that must be retained within the organization [16]. Employees with high commitment are willing to continue their association with the organization [35], and do the effort for drive and determine favorable organizational outcome across sectors [36].

Organizational commitment is individual's mental connection [3] to take side the organization [34] and desires to maintain membership in the organization [28] and to continue with the organization in the future [9]. Therefore, organizational commitment related with someone allegiance to their organization [7][19].

According to Meyer and Allen [37], Organizational Commitment can be measured through three components:

- Affective commitment involves the employee's emotional attachment to, identification with, and involvement in the organization;

- Continuance commitment involves commitment based on the costs that the employee associates with leaving the organization. This may be because of the loss of seniority for promotion or benefits; and

- Normative commitment involves employees' feelings of obligation to stay with the organization because they should; it is the right thing to do.
Based on literature review, the theoretical framework for this study is presented in Figure 1.

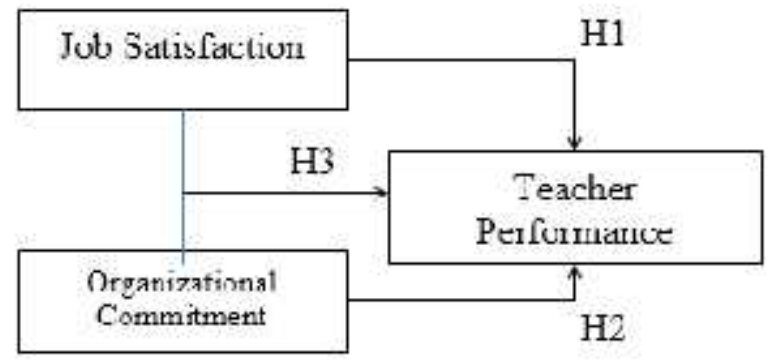

Fig. 1. Theoretical Framework

Based on theoretical framework, hypotheses for our study on the basis of literature and model are as follows:

$\mathrm{H} 1=$ There is effect of job satisfaction on teacher performance

$\mathrm{H} 2=$ There is effect of organizational commitment on teacher performance

$\mathrm{H} 3$ = There is effect of job satisfaction and organizational commitment on teacher performance

\section{RESEARCH METHODOLOGY}

This research used explanatory survey method. This method is considered appropriate for this study to gather factual information through the questionnaires. Respondents are 71 teachers of vocational high school in Bandung, West Java, Indonesia.

The instrument of data collection was in the form of a model of questionnaire rating scale, consisting of three parts. The first part is a questionnaire to measure perception of respondents regarding teacher performance, derived from the five indicators of quality of work, precision work, and initiative in work, work ability, and communication. This section consists of 15 items. The second part is a questionnaire to measure the perception of respondents about job satisfaction, derived from four indicators: exit, voice, loyalty, and neglect. This section consists of 15 items. The third part is a questionnaire to measure perception of respondents regarding organizational commitment, outlined three indicators of affective commitment, continuance commitment, and normative commitment. This section consists of 12 items.

Descriptive statistics, using the average score, is used to obtain a picture of the level of respondents' perception about teacher performance, job satisfaction and organizational commitment. Inferential statistics using regression analysis was used to test the hypothesis.

\section{FINDINGS \& DISCUSSION}

\section{A. Teacher Performance}

The average score of teacher performance was 4.47. It showed the perception of respondents that teacher performance is very high. Table 1 presents the average score of each indicator of teacher performance. 
TABLE I. DESCRIPTION OF TEACHER PERFORMANCE

\begin{tabular}{ccc}
\hline Indicators & Average & Category \\
\hline Quality of work & 4.51 & Very high \\
Precision work & 4.45 & Very high \\
Initiative in work & 4.51 & Very high \\
Work ability & 4.64 & Very high \\
Communication & 4.26 & Very high \\
\hline Average & $\mathbf{4 . 4 7}$ & Very high \\
\hline
\end{tabular}

The highest score is the indicator of work ability. These results demonstrate the ability of teachers to lead classes, managing learning and assess student learning outcomes that are in very high category. Indicator of communication has the lowest average score. This result implies that the teacher is not optimal in communication. Teachers rarely provide tutoring services to students and rarely communicate with parents.

\section{B. Job Satisfaction}

Teacher job satisfaction is in high category as indicated by the average score of 4.19 . Table 2 presents the average score of each indicator of job satisfaction of teachers.

TABLE II. DESCRIPTION OF TEACHER JOB SATISFACTION

\begin{tabular}{ccc}
\hline Indicator & Average & Category \\
\hline Exit & 2.61 & Adequate \\
Voice & 4.07 & High \\
Loyalty & 4.55 & Very high \\
Neglect & 4.36 & Very high \\
\hline Average & $\mathbf{4 . 1 9}$ & High
\end{tabular}

The highest score is the indicator of loyalty. These results indicate that teachers have pride to work, obey in performing their duties, and efforts for the improvement of working conditions. Indicator exit is in adequate category. This result implies that teachers feel comfortable enough to work and does not intend to leave the job.

\section{Organizational Commitment}

Organizational commitment is in the category is very high, as indicated by the average score of 4.38 . Table 3 presents the average score of each indicator of organizational commitment.

TABLE III. DESCRIPTION OF ORGANIZATIONAL COMMITMENT

\begin{tabular}{ccc}
\hline Indicator & Average & Category \\
\hline Affective Commitment & 4.53 & Very High \\
Continuance Commitment & 4.22 & Very High \\
Normative Commitment & 4.39 & Very High \\
\hline Average & $\mathbf{4 . 3 8}$ & Very High \\
\hline
\end{tabular}

Indicator of affective commitment has the highest average score in comparison with the average score of other indicators. This indicates that teachers have a positive emotional connection to the schools where they work. Teachers have a desire to work harder for the success of the school and have a strong desire to be part of the school. Indicator of continuance commitment has the lowest average score. This indicates that the teacher has not fully seen their work as a positive thing in the sense that there is little fear that allows them not fully optimized to provide the best, so they are still looking for other alternatives to work.

\section{H1: Influence of job satisfaction on teacher performance}

The linear regression equation that shows the effect of job satisfaction on the performance of teachers is $=33.780+$ $0.526(\mathrm{X})$. A positive sign $(+)$ indicates the relationship between the variables is one way. It means the higher job satisfaction of teachers, the higher the performance of teachers. Hypothesis testing showed the value of F-stat is greater than the value F-table (21.0986> 3.9798), with df $1=1$, df $2=2$ and $\alpha=0.05$. Thus job satisfaction significantly influences the performance of teachers. Based on the coefficient of determination, the influence of job satisfaction on teacher performance is $23.42 \%$.

These results are consistent with the results of several studies led to the conclusion of the influence of job satisfaction on the performance of teachers [15][19]. These results are also in line with some of the opinions of experts on the relationship between job satisfaction and performance. Job satisfaction has impact with performance [32][38]. Happy workers are more likely to be productive workers. Some researchers used to believe the relationship between job satisfaction and job performance was a myth. But a review of 300 studies suggested the correlation is pretty strong. Organizations with more satisfied employees tend to be more effective than organizations with fewer [34].

Job satisfaction leads to increased performance so employees do a better job in meeting the obligation, to encourage creativity, improve problem-solving and decisionmaking, and improve memory and attract a wide range of specific information [39]. When an employer offers favorable working conditions that make its service employees satisfied, the latter will in return tend to be committed to making an extra effort to the organization as a means of reciprocity for their employer, leading to a higher level of service quality. Employee satisfaction leads to higher service quality [40].

Teachers who are satisfied with their jobs usually have a high degree of professional capabilities and feel that they could manage, organize and perform specific tasks and behavior, even in case of failure [5]. Job satisfaction is one of these important factors. Disgruntled teachers who are not satisfied with their job will not be committed and productive [11]. 


\section{E. H2: Influence of organizational commitment to teacher performance}

The linear regression equation that shows the influence of organizational commitment on teacher performance is $=$ $23.032+0.826(\mathrm{X})$. A positive sign $(+)$ indicates the one way relationship that means the higher organizational commitment, the higher the performance of teachers. Hypothesis testing showed the value of F-stat is greater than the value F-table (58.2534> 3.9798), with df $1=1$, df $2=2$ and $\alpha=0.05$. Thus the organizational commitment significantly affects the performance of teachers. Based on the coefficient of determination, the influence of organizational commitment on teacher performance is $45.78 \%$.

These results are in line with the opinion of the experts who say that organizational commitment is important aspect that influence performance [19][41]. The organization's commitment results in increased performance [42]. This result is also supported by other similar research results stating that organizational commitment and significant positive effect on performance [41].

\section{F. H:3 Influence of job satisfaction and organizational commitment to teacher performance}

The linear regression equation that shows the effect of job satisfaction and organizational commitment on teacher performance is $=17.117+0.526(\mathrm{X} 1)+0.826(\mathrm{X} 2)$. A positive sign (+) indicates the relationship between the independent variables and the dependent variable is one way, which means any increase or decrease in one variable, it will be followed by an increase or decrease in the other variable, so that when the higher job satisfaction and organizational commitment of teachers, the more higher the performance of teachers. Hypothesis test indicate job satisfaction and organizational commitment significantly influence the performance of teachers.

This is consistent with several studies that have been done on teachers' organizational commitment and performance. Studies conducted by [32] have been successfully investigating the impact of job satisfaction and organizational commitment to performance. The sample was 200 employees among teaching staffs that are selected from different educational institutes of Pakistan. Regression analysis has been applied to make the results valid. The results of the study indicate strong positive relationship between job satisfaction and performance whereas organizational commitment has strong positive relation with performance and attitude towards work. The study identifies significant impact of organizational commitment on job satisfaction of employees working in educational sector.

A similar study has been conducted by several researchers. All the results of the study concluded there is significant influence on job satisfaction and organizational commitment to performance [3][21][29].

\section{CONCLUSION AND SUGGESTION}

Teacher performance, including quality of work, precision work, initiative in work, ability to work, and communications is at very high category. Teacher job satisfaction measured through indicators of exit, voice, loyalty, and neglect is at the high category. Commitment of organizations including affective commitment, continuance commitment, and normative commitment is at very high category.

Job satisfaction positively and significantly impact on teacher performance. Thus, the increase of job satisfaction of teachers will be followed by an increase in teacher performance. Organizational commitment has a significant and positive effect on teacher performance. It shows that the commitment of the organization is a predictor of teacher performance improvement. The level of organizational commitment will be followed by the level of teacher performance.

To improve the teacher performance, it is necessary to synergize the job satisfaction and organizational commitment. The higher job satisfaction and the higher organizational commitment, it is expected that teacher performance will be improved. In this sense, the school principal has to pay attention on facilitating teachers in their job. In addition, the teachers have to reveal their positive side to maximize the potential for school organization.

\section{References}

[1] Vrgovic, I. J., \& Pavlovic, N. (2014). Relationship Between The School Principal Leadership Style and Teachers' Job Satisfaction In Serbia. Montenegrin Journal of Economics, 10(1), 43-57.

[2] Noordin, F., Rashid, R. M., Ghani, R., Aripin, R., \& Darus, Z. (2010). Teacher Professionalisation and Organisational Commitment: Evidence From Malaysia. International Business \& Economics Research Journal, 9(2), 49-58

[3] Danish, R. Q., Draz, U., \& Ali, H. Y. (2015). Impact of Organizational Climate on Job Satisfaction and Organizational Commitment in Education Sector of Pakistan. American Journal of Mobile Systems, Applications and Services, 1(2), 102-109.

[4] Balwaria, R. R. (2013). A Study of Job Satisfaction of Teacher Educators Associated With Professional Variable. International Educational E-Journal, II(IV), 77-96.

[5] Gkolia, A., Belias, D., \& Koustelios, A. (2014). Teacher's Job Satisfaction and Self-efficacy: A Review. European Scientific Journal, 10(22), 321-342.

[6] Rahim, N., \& Razzak, S. (2013). Job Satisfaction among the Primary Public and Private School Teachers of Karachi. Journal of Education and Social Sciences, 1(1), 20-30.

[7] Hussain, M. A., Ahmedy, I., \& Haider, S. Z. (2014). Investigating the relationship among Organizational Commitment, Job Satisfaction and Emotional Intelligence-Evidence from Teachers at Secondary Level in Pakistan. Journal of Education and Social Sciences, 2(2), 127-143.

[8] Aslam, R. (2012). Investigating the Relationship of OCB with Job Satisfaction, Organizational Commitment and Turnover Intensions (A case study on teaching staff of University of the Punjab). International Journal of Economics and Management Sciences, 1(9), 90-100.

[9] Rehman, K., Rehman, Z., Saif, N., Khan, A. S., Nawaz, A., \& Rehman, S. (2013). Impacts of Job Satisfaction on Organizational Commitment: A Theoretical Model for Academicians in HEI of Developing Countries Like Pakistan. International Journal of Academic Research in Accounting, Finance and Management Sciences, 3(1), 80-89.

[10] Naheed, K., \& Iqbal, S. (2016). Relationship of Motivation and SelfEfficacy with Job Satisfaction of Teachers A Case Study of DG - Khan Education Sector. Journal of Culture, Society and Development, 15(2016), 27-30. 
[11] Usop, A. M., Askandar, K., Kadtong, M. L., \& Usop, D. S. (2013). Work Performance and Job Satisfaction among Teachers. International Journal of Humanities and Social Science, 3(5).

[12] Ruqaiya M, A., Khairuddin B, I., Zoharah B, O., Ramli B, B., \& Naresh, K. (2014). Public schools' Characteristics and Teacher Turnover in Oman. International Journal of Research Studies in Education, 3(1), 320.

[13] Shah, M. J., Rehman, M. U., Akhtar, G., Zafar, H., \& Riaz, A. (2012). Job Satisfaction and Motivation of Teachers of Public Educational Institutions. International Journal of Business and Social Science, 3(8), 271-281.

[14] Chamundeswari, S. (2013). Job Satisfaction and Performance of School Teachers. International Journal of Academic Research in Business and Social Sciences, 3(5), 420-428.

[15] Michaelowa, K. (2002). Teacher job satisfaction, student achievement, and the cost of primary education in Francophone Sub-Saharan Africa. . Hamburgisches Welt-Wirtschafts-Archiv (HWWA), Hamburg Institute of International Economics, Discussion Paper. No. 188.

[16] Garipağaoğlu, B. C.. (2013). Examining Organizational Commitment of Private School Teachers. Journal of Educational and Instructional Studies In The World, 3(2), 22-28.

[17] Bernardin, H. (2006). Human Resource Management: An Experiential Approach 4th Edition. New York: McGraw Hill Higher Education.

[18] Hosmani, A., \& Shambhushankar, B. (2014). Study on Impact of Quality of Work Life on Job Performance amongst Employees of Secunderabad Division of South Central Railway. Research Journal of Management Sciences, 3(11), 8-11.

[19] Wahyuni, D. U., Christiananta, B., \& Eliyana, A. (2014). Influence of Organizational Commitment, Transactional Leadership, and Servant Leadership to the Work Motivation, Work Satisfaction and Work Performance of Teachers at Private Senior High Schools in Surabaya. Educational Research International, 3(2), 82-96.

[20] Şentuna, M. (2015). Investigation of Job Satisfaction, Organizational Commitment and Self Esteem of Physical Education Teachers According to the Gender. International Online Journal of Educational Sciences, 7(2), 93-101.

[21] Omidifar, R. (2013). Leadership Style, Organizational Commitment and Job Satisfaction: A Case Study on High School Principals in Tehran, Iran. American Journal of Humanities and Social Sciences, 1(4), 263267.

[22] Gangai, K. N., \& R. Agrawal. (2015). Job Satisfaction and Organizational Commitment: Is It important for Employee Performance. International Journal of Management and Research, 5(4), 269-278.

[23] Cong, N. N., Van, D. N., Huu, T. H., \& Thi Kim, N. N. (2013). Factors affecting Job Satisfaction of Teachers of Hue University in Vietnam. Journal of Research in International Business and Management, 3(5), 169-174.

[24] Ronald, M. O., Aisha, K., \& Dennis, M. B. (2013). Job Satisfaction and Organizational Commitment: A Cross Sectional Study with Reference to Teachers in Technical \& Management Institute. Global Journal of Management and Business Research Administration and Management, 13(8), 23-29.

[25] Sargent, T., \& Hannum, E. (2005). Keeping Teachers Happy: Job Satisfaction among Primary School Teachers in Rural Northwest China. Comparative Education Review, 49(2), 173-204.

[26] Rao, D. B., \& Sridhar, D. (2003). Job Satisfaction of School Teacher. New Delhi: Discovery Publishing House.
[27] Arif, B., \& Farooqi, Y. A. (2014). Impact of Work Life Balance on Job Satisfaction and Organizational Commitment Among University Teachers: A Case Study of University of Gujrat, Pakistan. International Journal of Multidisciplinary Sciences and Engineering, 5(9), 24-29.K. Elissa, "Title of paper if known," unpublished.

[28] Akpan, C. (2013). Job Security and Job Satisfaction as Determinants of Organizational Commitment among University Teachers in Cross River State, Nigeria. British Journal of Education, 1(2), 82-93.J. Clerk Maxwell, A Treatise on Electricity and Magnetism, 3rd ed., vol. 2. Oxford: Clarendon, 1892, pp.68-73.

[29] Dery, E., \& Puopiel, F. (2013). Job Satisfaction and Organizational Commitment among Teachers of Public Senior High Schools: A Case Study of Tamale Metropolis. Information and Knowledge Management, $3(11), 47-52$.

[30] Spector, P. E. (2012). Job Satisfaction, Application, Assessment, Causes, and Consequence. New Delhi: SAGE Publications, Inc.

[31] Yucel, I., \& Bektas, C. (2012). Job Satisfaction, Organizational Commitment and Demographic Characteristics among Teachers in Turkey: Younger is Better? Procedia - Social and Behavioral Sciences, 46(2012), 1598-1608

[32] Imran, H., Arif, I., Cheema, S., \& M.Azeem. (2014). Relationship between Job Satisfaction, Job Performance, Attitude towards Work, and Organizational Commitment. Entrepreneurship and Innovation Management Journal, 2(2), 135-144.

[33] Ramatulasamma, K. (2003). Job Satisfaction off Teachers Educators. New Delhi: Discovery Publishing House.

[34] Robbins, S., \& Judge, T. (2013). Organizational Behavior, 15th ed. New York: Pearson Education, Inc.

[35] Nagar, K. (2012). Organizational Commitment and Job Satisfaction among Teachers during Times of Burnout. VIKALPA, 37(2), 43-60.

[36] Jonathan, H., Darroux, C., \& Massele, J. (2013). Perceived Job Satisfaction and Its Impact on Organizational Commitment: An Empirical Study of Public Secondary School Teachers in Dodoma, Tanzania. IOSR Journal of Business and Management, 13(3), 41-52.

[37] Luthans, F. (2011). Organizational Behavior: An Evidence-Based Approach, Twelfth Edition. New York: McGraw-Hill.

[38] Faleh, A., \& As'ad, H. (2010). Measuring the Effect of Academic Teachers of Public Senior High Schools: A Case Study of Tamale Metropolis. Information and University in Jordan. International Business Research, 4(2), 153-160.

[39] Talasaz, Z. H., Saadoldin, S. N., \& Shakeri, M. T. (2014). The Relationship between Job Satisfaction and Job Performance among Midwives Working in Healthcare Centers of Mashhad, Iran. Journal of Midwivery \& Reproductive Health, 2(3), 157-164.

[40] Indermun, M. V., \& SaheedBayat, M. (2013). The Job SatisfactionEmployee Performance Relationship: A Theoretical Perspective. International journal of Innovative Research in Management, 2(1), 1-9.

[41] Memari, N., Mahdieh, O., \& Marnani, A. B. (2013). The impact of Organizational Commitment on Employees Job Performance. "A study of Meli bank". Interdisciplinary Journal Of Contemporary Research In Business, 5(5), 164-171

[42] Khan, M. R., Ziauddin, Jam, F. A., \& Ramay, M. (2010). The Impacts of Organizational Commitment on Employee Job Performance. European Journal of Social Sciences, 15(3), 292-298. 